\title{
通信販売の下着に対する女子大学生と社会人女性の 意識の測定
}

\author{
田村和 子

\section{Measurement of Consciousness of Female University Students and Employed Women for the Mail-Order Underwear}

\author{
Kazuko Tamura
}

\begin{abstract}
In this paper, female university students' and employed women's consciousness for the mail order underwear was studied. The results obtained by factor analysis are as follows : 1) The factor structure of their consciousness for the mail order underwear is interpreted as (F1) feel ashamed of measuring size, (F2) a many kinds of form and size of goods, (F3) returning or exchanging goods. 2) As a result of comparing the factor score, it was found that the students and employed women who bought in mail order underwear were strongly interested in a variety of merchandise and size, and were lower a sense of returning or exchanging goods than who didn't buy. 3) It was found that the student women were more ashamed of measuring size than employed women and that they felt.
\end{abstract}

(Received June 22, 1998)

(Accepted for Publication March 15, 1999)

\section{1. 緒 言}

従来マーケッティングの分野では, 購買行動やフ アッション行動の差異を説明する要因として, 性や 年齢, 未既婚, 学歴や職業, 収入などが用いられ, これらを基準に市場細分化が行われてきた。 しか し，オイルショック以降では，好みや価值観の多様 化が進み, 同じ世代の女性であっても, 全く違った 意識や行動をとる現象がみられ，次第にその説明力 が弱まってきた ${ }^{1)}$.

今日の社会においては，下着を通信販売で購入す るという被服行動む個人の内面的な要因や他者を含 む外面的な要因によって影響されていると考えられ る．例えば，下着に対する意識や，通信販売に対す る意識，そして，個人の意識等，多方面にわたる意 識を考えることができる.

しかしながら，下着を通信販売で購入する要因に
ついて科学的な分析はいまだ数少なく, 現代女性の 下着観について被服心理的な立場から研究されたも のもいまだ数少ない2 ${ }^{2 \sim 4)}$.

そこで, 本研究では女子大学生と社会人女性を対 象として, 通販下着に対する意識について調査し, 両者の意識の比較, 通販利用者之非利用者の比較, そして, 下着を通信販売で購入するという被服行動 の要因を明らかにするために，因子分析を用いて分 析した.

\section{2. 調宜方法}

\section{1 調㚗対象および方法}

調查は高知県にある大学の女子学生204名（18～ 24歳）と社会人女性215名（18～40歳）を対象に，平 成 6 年12月初旬から中旬にかけて行った.

社会人の年齢は18～24歳84名，25～30歳52名，31

会員, Member, 高知大学教育学部, Faculty of Education, Kochi, University, Kochi 
〜 35 歳 14 名, $36 \sim 40$ 歳 65 名で, 職種 は会社員 (59\%), 看護婦 (14\%), 公務員 (16\%) などで, 全 員がフルタイムの仕事に従事している.

表 1 に通信販売の下着 (以下, 通販下着と略す) の利用状況を示す. 分析では, 現在, 通販下着を利 用している大学生 117 名, 社会人113名を利用者, 利 用したことがない大学生68名, 社会人72名を非利用 者として比較した。

社会人は配票留置法によって行い，大学生につい ては質問紙を配布し, 調査の説明をした後, その場 で回答させ回収した。

分析に用いることができた有効票は, 配布数に対 して, 大学生の場合 $92.7 \%$ にたる204名, 社会人の 場合 $93.1 \%$ に当たる215名である.

\section{2 調查の内容}

\subsection{1 通販下着に対するイメージや考え等の調 查 (予備調查)}

まず, 質問項目の設定にあたり, 女子大学生, 社 会人女性, 各30名を対象に, 通販下着に対するイメ ージや考え等について調査を行った.

大学生30名に対しては, 自由記述で,「通販下着に ついて, 日頃抱いているイメージや考え等」につい て400 600字程度の作文を書かせた。 社会人 30 名に ついては同様の内容でインタビュ一調查を行った.

両者から得られた意識を整理した結果, 返品・交 換, カタログショッピングなど下着の通信販売に対 する意識と, 経済性, 品質, サイズ・品数, 衛生面, 外観, ファッション性といった下着にっいての意 識, そして, 下着を購入する際の試着, 計測, 店員 等に対する恥ずかしさの意識の 3 つの内容に分けら れた.

\subsection{2 測定尺度}

被服に対する関心の程度について,「被験者の被 服に対する多方面にわたる意識とこれに関する被験 者の活動性を含む」とRosencranz は定義してい
る5). 通販下着に対する関心についても同様に考え られ，通販下着に対する意識の測定は，下着に対す る意識や通信販売に対する意識, そして, 個人の恥 ずかしさの意識等, 多方面にわたる意識を含めて测 定項目を考える必要がある.

そこで, 本研究では, 通販下着の意識の構成要件 として, 経済性, 品質, サイズ・品数, 衛生面, 試 着・計測, 販売員の態度, 返品・交換, 外観 $(フ ァ$ ッション性), カタログショッピングの 9 つを考え 「通販下着に対する意識の測定項目」とした. 質問紙 を作成し，プリテストを大学生，社会人について行 った後, 調查を実施した。

「下着」の範囲については，質問紙に「ここでいう 下着はブラジャー, ガードル類（ボディースーツな ど), ランジェリー類 (キャミソールなど), ショー ッをいいます」と記入した。

各意見項目についての回答は, 中立的な評定に集 中することを避けるために 4 段階評定とし,「非常 にそう思う」を 4 点, 「少しそう思う」を 3 点, 「あ まりそう思わない」を 2 点,「全くそう思わない」を 1 点として得点化した.

また，別に個人情報として，職業，年齢の他に， 通販利用者に対しては利用回数, 購入商品とその価 格, 利用カタログ名を調查した. 非利用者に対して はカタログを見たことがあるかどうか, 今後利用し たいかどうか, 利用していない理由, 市販店での購 入商品とその価格について調查した（資料 1).

\section{3 デー夕処理}

まず, 大学生と社会人別に, 各質問項目への反応 の平均値を算出し, 高得点の項目と低得点の項目か ら，通販下着に対する意識を明らかにした。

次に, 大学生之社会人の差, 通販利用者之非利用 者の差を明らかにするために, 項目別に平均値の差 の検定 ( $\mathrm{t}$ 検定) を行った.

さらに，通販下着に対する意識，すなわち下着を

Table 1 Number or subjects who bought in Mail-Order Underwear, or who didn't buy. (The number of people)

\begin{tabular}{crrr}
\hline \hline & 大学生 & 社会人 & \multicolumn{1}{c}{ 計 } \\
\hline 現在, 通販下着を利用している & 117 & 133 & 250 \\
利用したことがあるが, 2度と利用しない & 19 & 10 & 29 \\
利用したことがない & 68 & 72 & 140 \\
\hline 計 & 204 & 215 & 419 \\
\hline
\end{tabular}


（資料 1）

○以下の事項に記入、あるいは当てはまるものに○印をお䫛いします。

I . 職業〈(1)会社員 (2)医業 (3)公務員 (4)サービス業 (5)自由業 (6)学生（回生) (7)その他

II. 年路〈(1) $18 \sim 24$ 葴 (2) $25 \sim 30$ 歳 (3) $31 \sim 35$ 歳 (5) $36 \sim 40$ 歳 (6) 40 歳以上〉

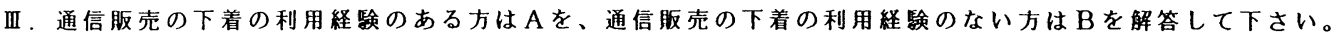

A．利用経験のある方は以下の事項に記入、あるいは当てはまるものに○印をお願いします

(1) 通信肘売をく年間) 程、もしくは（回）〈(1)利用している

（2）購入形偟は、〈(1)個人 (2)友達や同僚などクループ〉である。

(3) 瞒入するもの、していたものには○、しないものには×をそれそれつけて下さい。

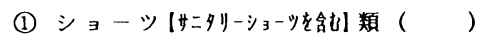
(2) ブラジャー類（）

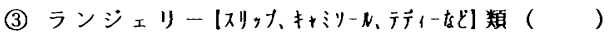

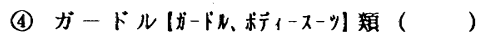

(4) (3)で○をつけた下着（自分の下着）は、通眅で普段、だいたい1收あたりいくらの物を睡入しますか。
(1) ショーツ【サニタリーショーツを含わ類 (
) 円
(2) ブラジャ一類
) 円

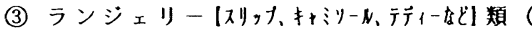
) 円

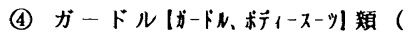

(5) 現在、利用している、もしくは利用していた通信肘売のカタログは である。

(6) (1)で、(2)利用していたがやめたと答えた方は、その主な理由を下記から選び、2つ○印をつけて下さい。
(1)自分のイメージした下着と実物が違っていた
(3)注文するのが面倒だ
(4)品質が良くなかった

(2) 届いた下着のサイズが合わなかった

(5)その他（理由を記入して下さい）

（7）通信販売を今後、〈(1)利用してみたい（2)利用するつもりはない〉.

B.一度も利用したことがない方のみお答え下さい

(1) 通眅下着のカタロクは見た事がくあるない〉。

(2) 今後, 通信眅壳の下着を〈(1)利用してみたい (2)利用しない〉。

(3)利用しない主な理由を下記から選び、2つ○印をつけて下さい。

(1)実物を確かめられない

(2) 試着でない

(3) 注文するのが面倒だ

(4) 安っぽい感じがする

(5)その他（理由を記入してください）

（4）普段、下着を購入する場合、だいたい1枚あたりいくらの物を購入しますか。
(1) ショーツ
) 円
(2) ブラジャ-
）円

通販で購入するという被服行動の要因を明らかにす るために因子分析を行った，因子分析はピアソンの 相関係数を用い, 主因子法により回転前の因子行列 を求め, バリマックス回転により最終的な因子行列 を求めた. 因子の数は, 因子の固有值が 1.0 以上で, 抽出された因子の累積寄与率が70\%を越えることを 基準にして決定した。これらの計算は, 高知大学情 報処理センターのコンピュータを使用し, ANA-
LYST の統計サブプログラムを用いて行った.

\section{3. 調㚗結黑および考察}

\section{1 大学生と社会人の意識の差}

大学生と社会人の各意見項目の平均値を表 2 に示 す. 意見項目の文章は簡略化している. 大学生，社 会人ともに高い得点を得た項目は,「カタログを見 
るとウィンドウショッピングをしているような気持 ちになり楽しい」,「カタログを見るのに時間をかけ る」,「試着中の姿を店員に見られるのは䎵ずかし い」,「サイズを測っているのを他の人に見られるの は恥ずかしい」,「通販で届いた下着の種類が間違っ ていたら返品・交換する」などである．その反対に 低い得点を得た質問項目は，「通販だとセクシーな 下着を購入したい」,「通販の下着はセクシーなもの を買う」「「カタログから素材感・肌触りを判断でき る」などであった。

大学生と社会人間で, 平均的に差があるかどうか を検定したところ,「下着を購入する際, 店員に相談 しづらい」，「下着を買っているところを他人に見ら れたくない」,「サイズを測っているのを他の人に見 られるのは恥ずかしい」が 1\%水準で,「カタログを 見ると，ウィンドウショッピングをしているような 気持ちになり楽しい」が $5 \%$ 水準で有意であり，い ずれあ大学生の方が得点が高かった。

以上の結果から, 大学生, 社会人両者ともに, 通 販の下着を安いと感じており, 種類, サイズの間違 いは返品・交換を希望し，カタログショッピングを 楽しんでいることがわかった，そして，大学生の方 が社会人よりあ店員に相談しづらく，サイズ計測や 購入を見られるのが恥ずかしいと思っていることが わかった。

\section{2 利用者と非利用者の意識の差}

通信販売を現在利用している者と利用していない 者の各意見項目の平均値を算出した。結果を表 3 に 示す.

利用者と非利用者間で，平均得点に差があるかど うかを検定した．1\%水準で，「通販の下着はサイズ が豊富だ」,「ブラジャーなど試着しないと分からな い屯のを購入する」，「下着を購入する際，店員に相 談しづらい」,「通販で届いた下着のサイズがあわな かったら返品・交換するほうだ」「「通販の下着は色 柄物のショーツを買う」「「カタログを見ると, ウィ ンドウショッピングをしているような気持ちになり 楽しい」,「カタログから下着の素材感・肌触りを判 断できる」が有意であり,「下着のサイズが合わなか ったら返品・交換するほうだ」以外はいずれす利用 者の方が得点が高かった.

$5 \%$ 水準では,「通販の下着は市販の下着より安 い」,「他人が試着していないので衛生的だ」,「通販 で届いた下着の種類が間違っていたら，返品・交換
するほうだ」,「通販で届いた下着のイメージが違っ ていたら返品・交換するほうだ」「「通販の下着はセ クシーなあのを買う」,「カタログを見るのに時間を かける」が有意であり,「下着のイメージが違ってい たら返品・交換するほうだ」以外はいずれす利用者 の方が得点が高かった。

以上の結果から，利用者の方がサイズの豊富さを 認め, カタログショッピングを楽しんでおり, 返品

・交換を希望する意識が低いことがわかった.

\section{3 通販下着に対する意識の因子構造}

さらに，下着を通販で購入するという被服行動の 要因を明らかにするために，因子分析を行った．因 子の解釈は, 因子負荷量 0.45 以上の項目で, 因子負 荷量が大きい項目の内容を中心に行った.

抽出された因子は 3 因子である. 第 1 因子から第 3 因子を特徴づける質問項目および因子負荷量を表 4 に示す.

まず，第 1 因子に含まれる 6 項目をみると，店員 に下着姿を見られたり，サイズを聞かれたり，測定 されたり，サイズ測定を他人に見られるのは恥ずか しいという内容であるので，「試着・計測の恥ずか しさ」の因子と解釈した.

自由記述の作文には，通販下着の購入は，「下着売 場に行く際の恥ずかしさがない」「店員の眼を気に せず，選択・購入ができる」，「補正下着を購入しや すい」，「自分以外の人に何を買ったかわからない」 等の記述むみられた。一方, 市販店での下着の購入 については，「自分がほしい下着を店員に説明した り，長い時間さがすのは気がひける」「他の人や店 員の眼が気になって下着をよく選べない」等の記述 があった. カタログを用いての下着の選択・購入は 人の眼を気にする必要がないし, 試着・計測の恥ず かしさあなく，ゆとりを持って選択ができることが 魅力になっているあのと考えられる.

第 2 因子は通販下着は品数やサイズが豊富なの で，試着しなくてあ購入できるという内容であるの で,「サイズ・品数の豊富さ」の因子と解釈した。

利用しているカタログの名前を調查したところ， 全体で27の名前があげられ，複数利用者は女子学生 で56\%，社会人女性で34\%あった，通信販売の力夕 ログの豊富さもサイズと品数の豊富さにつながって いるあのと考えられる.

第 3 因子は，下着のサイズ，種類，イメージが違 っていたら返品・交換をするという内容であるの 
Table 2 Comparision of mean score between University Studens and Employed women. (Students : $\mathrm{n}=204$ Women $: \mathrm{n}=215$ )

\begin{tabular}{|c|c|c|c|c|}
\hline 尺 度 & $\begin{array}{lll}\text { 質 問 内 容 } & \end{array}$ & 大学生 & 社会人 & $\mathrm{t}$ 検定 \\
\hline 経済性 & $\begin{array}{l}\text { 通販の下着は市販の下着より安い } \\
\text { 必要なもだけを買うので経济的だ }\end{array}$ & 3.07 & 3.07 & \\
\hline 品 質 & $\begin{array}{l}\text { 市販の下着よりも安っぽい } \\
\text { 市販の下着よりも、品質 (生地, 縫製) が良 } \\
\text { くない }\end{array}$ & $\begin{array}{l}2.55 \\
2.36\end{array}$ & $\begin{array}{l}2.59 \\
2.34\end{array}$ & \\
\hline $\begin{array}{l}\text { サイズ } \\
\text { 品 数 }\end{array}$ & $\begin{array}{l}\text { 通販の下着は品数が多い } \\
\text { 通販下着はサイズが豊富だ } \\
\text { ブラジャな゙ど、試着しないとわからいも } \\
\text { のを購入する }\end{array}$ & $\begin{array}{l}2.49 \\
2.56 \\
2.42\end{array}$ & $\begin{array}{l}2.45 \\
2.45 \\
2.26\end{array}$ & \\
\hline 衛生面 & 他人が試着していないので衛生的だ & 2.45 & 2.37 & \\
\hline $\begin{array}{ll}\text { 試 } & \text { 着 } \\
\text { 計 測 }\end{array}$ & 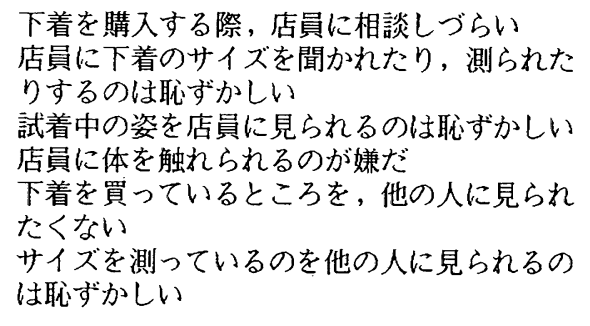 & $\begin{array}{l}2.54 \\
2.72 \\
\\
3.22 \\
2.79 \\
2.69 \\
3.17\end{array}$ & $\begin{array}{l}2.26 \\
2.62 \\
\\
3.08 \\
2.71 \\
2.15 \\
2.87\end{array}$ & $* *$ \\
\hline $\begin{array}{l}\text { 店員の } \\
\text { 態 度 }\end{array}$ & $\begin{array}{l}\text { 試着中に店員にせかされるのが嫌いだ } \\
\text { 店員の態度を押し売り的と思うことがある }\end{array}$ & $\begin{array}{l}2.31 \\
2.80\end{array}$ & $\begin{array}{l}2.37 \\
2.67\end{array}$ & \\
\hline $\begin{array}{l}\text { 返 品 } \\
\text { 交 換 }\end{array}$ & 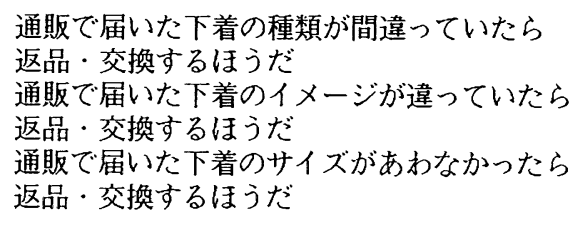 & $\begin{array}{l}3.12 \\
2.52 \\
3.09\end{array}$ & $\begin{array}{l}3.10 \\
2.61 \\
3.03\end{array}$ & \\
\hline $\begin{array}{c}\text { 外 観 } \\
\text { ファッション性 }\end{array}$ & $\begin{array}{l}\text { 通販だとセクシーな下着を購入したい } \\
\text { 通販の下着はカラフルな色やデサンのもの } \\
\text { が多い } \\
\text { 通販の下着はセクシーなものを買う } \\
\text { 通販の下着は色柄物のショーツを買う }\end{array}$ & $\begin{array}{l}1.89 \\
2.67 \\
1.40 \\
1.77\end{array}$ & $\begin{array}{l}1.80 \\
2.63 \\
1.38 \\
1.81\end{array}$ & \\
\hline $\begin{array}{l}\text { カタログ } \\
\text { ショッピング }\end{array}$ & $\begin{array}{l}\text { カタログを見るのに時間をかける } \\
\text { カタログを見るとウィイ゙ウショッピング } \\
\text { をしているような気持ちになり楽しい } \\
\text { カタログから下着の素材感・肌触りを判断 } \\
\text { できる } \\
\text { 店員の説明よりカタログの商品説明の方がわ } \\
\text { かりやすい }\end{array}$ & $\begin{array}{l}3.09 \\
3.38 \\
1.62 \\
2.21\end{array}$ & $\begin{array}{l}2.99 \\
3.20 \\
1.76 \\
2.16\end{array}$ & $*$ \\
\hline
\end{tabular}

$* 5 \%$ 有意 $* * 1 \%$ 有意 
Table 3 Comparision of mean score between University Students and Employed women who bought in Mail-Order Underwear. or who didn't buy. (Students and Women who bought : $\mathrm{n}=250$ Students and Women who didn't in buy : $n=140$ )

\begin{tabular}{|c|c|c|c|c|}
\hline 尺 度 & 問 内 容 & 利用者 & 非利用者 & t検定 \\
\hline 経済性 & $\begin{array}{l}\text { 通販の下着は市販の下着より安い } \\
\text { 必要なものだけを買うので経済的だ }\end{array}$ & $\begin{array}{l}3.15 \\
2.61\end{array}$ & $\begin{array}{l}2.94 \\
2.39\end{array}$ & $*$ \\
\hline 品 質 & $\begin{array}{l}\text { 市販の下着よりも安っぽい } \\
\text { 市販の下着よりも, 品質 (生地, 縫製) が良 } \\
\text { くない }\end{array}$ & $\begin{array}{l}2.66 \\
2.39\end{array}$ & $\begin{array}{l}2.51 \\
2.31\end{array}$ & \\
\hline $\begin{array}{l}\text { サイズ } \\
\text { 品 数 }\end{array}$ & $\begin{array}{l}\text { 通販の下着は品数が多い } \\
\text { 通販下着はサイズが豊富犬゙ } \\
\text { ブラジャ一など, 試着しないとわからないも } \\
\text { のを購入する }\end{array}$ & $\begin{array}{l}2.59 \\
2.59 \\
2.81\end{array}$ & $\begin{array}{l}2.31 \\
2.37 \\
1.59\end{array}$ & $\begin{array}{l}* * \\
* *\end{array}$ \\
\hline 衛生面 & 他人が試着していないので衛生的だ & 2.44 & 2.25 & $*$ \\
\hline $\begin{array}{l}\text { 試 着 } \\
\text { 計 測 }\end{array}$ & $\begin{array}{l}\text { 下着を購入する際, 店員に相談しづらい } \\
\text { 店員に下着のサイズを聞かれた，測られた } \\
\text { クするのは恥ずかしい } \\
\text { 試着中の姿を店員に見られるのは恥ずかしい } \\
\text { 店員に体を触れられるのが嫌だ } \\
\text { 下着を買っているところを, 他の人に見られ } \\
\text { たくない } \\
\text { サイズを測っているのを他の人に見られるの } \\
\text { は恥ずかしい }\end{array}$ & $\begin{array}{l}2.48 \\
2.67 \\
3.13 \\
2.74 \\
2.39 \\
3.05\end{array}$ & $\begin{array}{l}2.33 \\
2.69 \\
3.18 \\
2.79 \\
2.39 \\
2.93\end{array}$ & $* *$ \\
\hline $\begin{array}{l}\text { 店員の } \\
\text { 態 度 }\end{array}$ & $\begin{array}{l}\text { 試着中に店員にせかされるのが嫌いだ } \\
\text { 店員の態度を押し売り的と思うことがある }\end{array}$ & $\begin{array}{l}2.32 \\
2.72\end{array}$ & $\begin{array}{l}2.41 \\
2.74\end{array}$ & \\
\hline $\begin{array}{ll}\text { 返 品 } \\
\text { 交 換 }\end{array}$ & $\begin{array}{l}\text { 通販で届いた下着の種類が間違っていたら } \\
\text { 返品・交換するほうだ } \\
\text { 通販で届いた下着のイメージが違っていたら } \\
\text { 返品・交換するほうだ } \\
\text { 通販で届いた下着のサイズがあわなかったら } \\
\text { 返品・交換するほうだ }\end{array}$ & $\begin{array}{l}3.02 \\
2.47 \\
2.94\end{array}$ & $\begin{array}{l}2.27 \\
2.74 \\
3.21\end{array}$ & * \\
\hline$\underset{\text { ファッション性 }}{\text { 外 }}$ & $\begin{array}{l}\text { 通販だとセクシーな下着を購入したい } \\
\text { 通販の下着はカラフルな色や゙ザインのもの } \\
\text { が多い } \\
\text { 通販の下着はセクシーなものを買う } \\
\text { 通販の下着は色柄物のショーツを買う }\end{array}$ & $\begin{array}{l}1.46 \\
2.69 \\
1.46 \\
2.09\end{array}$ & $\begin{array}{l}1.28 \\
2.65 \\
1.28 \\
1.28\end{array}$ & $*$ \\
\hline $\begin{array}{l}\text { カタログ } \\
\text { ショッピング }\end{array}$ & $\begin{array}{l}\text { カタログを見るのに時間をかける } \\
\text { カタログを見るとウィンドウショッピング } \\
\text { をしているような気持ちになり楽しい } \\
\text { カタログから下着の素材感・肌触りを判断 } \\
\text { できる } \\
\text { 店員の説明よりカタログの商品説明の方がわ } \\
\text { かりやすい }\end{array}$ & $\begin{array}{l}3.27 \\
3.40 \\
1.78 \\
2.27\end{array}$ & $\begin{array}{l}2.80 \\
3.11 \\
1.57 \\
2.13\end{array}$ & $\begin{array}{c}* \\
* *\end{array}$ \\
\hline
\end{tabular}


で，「返品・交換」の因子と解釈した．これらは，通 販で下着を購入する上で避けられない面であり，こ の面に対して, 通販には, 返品・交換のシステムが ある．自由記述の作文にあ「返品・交換ができて便 利」「返品・交換は面倒だ」という記述がみられた。

以上の結果から, 通販下着に対する意識は, 「試着 ・計測の恥ずかしさ」,「サイズと品数の豊富さ」, 「返品・交換」の 3 因子によって構成されているこ とがわかった。

\section{4 因子得点の比較}

次に，因子分析から抽出された 3 因子に関して， 因子得点の平均值を算出した。 結果を図 1 に示す.

図から, 利用者は, サイズと品数の豊富さを認め, 返品・交換をする意識が低いことがわかる.

利用者と非利用者間で，平均值に差があるかどう かを検定 ( $\mathrm{t}$ 検定) したところ，サイズと品数の豊富 さにおいて $1 \%$ 水準で差が認められ，返品・交換に ついては 5\%水準で有意な差が認められた。

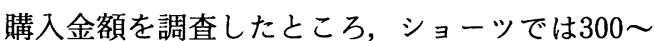
500 円以下が大学生 $36 \%$, 社会人 $35 \%$ と最も多く, 次 いで，800〜1,000円以下が大学生19\%，社会人 $30 \%$ であった．ブラジャーでは1,500〜2,000円以下が大 学生 $28 \%$, 社会人 $34 \%$ と最む多く, 次いで, 2,500 3,000 円以下が大学生 $21 \%$, 社会人 $24 \%$ あっった。こ
のことから，利用者は安い值段であるので，わざわ ざ返品・交換しなくてもよい, 返品・交換は面倒だ という意識があるあのと考えられる。

自由記述の作文にも,「たかが下着 1 枚で, 返品。 交換するのは恥ずかしくためらいがちである」「「夕 ンスの肥やしになっていることが多い」といった記 述がみられる，自分のイメージどおりの色・柄，素 材・肌ざわり，そして，体にフィットした下着の購 入は難しく, 利用者の方が妥協しているものと推察 される.

そして，試着・計測の恥ずかしさについては，大 学生の方が意識しており, 大学生と社会人間で, 平 均値に差があるかどうかを検定（ $\mathrm{t}$ 検定）したとこ ろ，1\%水準で有意な差が認められた。

以上の結果から, 利用者は非利用者よりあサイズ と品数の豊富さを認め, 返品・交換をする意識が低 いことがわかった。 また，試着・計測の恥ずかしさ については, 社会人より大学生の方が意識している ことがわかった。

\section{4. 結 論}

女子大学生と社会人女性を対象として, 通販下着 に対する意識を調查した.

調查結果を因子分析したところ，「試着・計測の 恥ずかしさ」,「サイズと品数の豊富さ」,「返品・交

Table 4 Factor loading of three factors for consciousness of Mail-Order Underwear

\begin{tabular}{|c|c|c|c|}
\hline 子 & 内 & $\begin{array}{l}\text { 因 子 } \\
\text { 負荷量 }\end{array}$ & 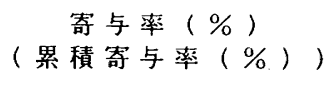 \\
\hline 第 1 因子 & 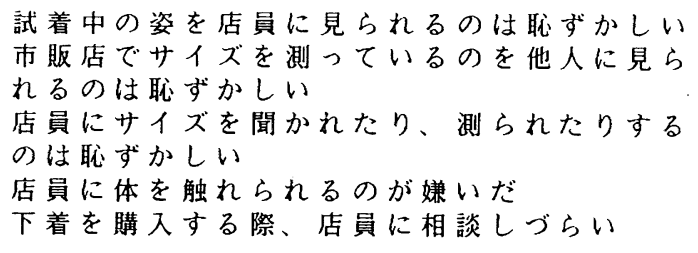 & $\begin{array}{l}0.80 \\
0.73 \\
0.70 \\
0.63 \\
0.58\end{array}$ & $\begin{array}{l}35.7 \\
(35.7)\end{array}$ \\
\hline 第 2 因子 & $\begin{array}{l}\text { 通販の下着はサイズが豊富だ } \\
\text { ブラジャーなど、試着しないとわからないも } \\
\text { のを購入する } \\
\text { 通販の下着は品数が多い }\end{array}$ & $\begin{array}{l}0.62 \\
0.57 \\
0.51\end{array}$ & $\begin{array}{l}20.2 \\
(55.8)\end{array}$ \\
\hline 第 3 因子 & $\begin{array}{l}\text { 通販で届いた下着のサイズがあわなかったら } \\
\text { 返品・交換するほうだ } \\
\text { 通販で届いた下着の種類が間違っていたら、 } \\
\text { 返品・交換するほうだ遮販で届いた下着のイメージが違っていたら } \\
\text { 返品・交換するほうだ }\end{array}$ & $\begin{array}{l}0.87 \\
0.80 \\
0.72\end{array}$ & $\begin{array}{l}17.3 \\
(73.1)\end{array}$ \\
\hline
\end{tabular}




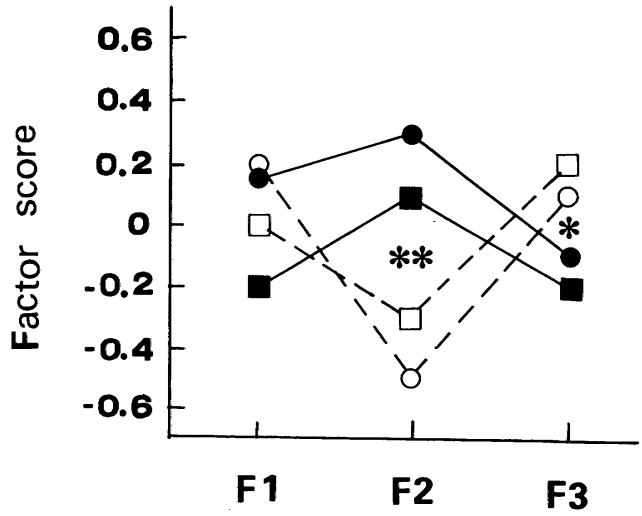

Fig. 1 Comparison of mean factor score

F1: Feel ashamed of measuring size F2 : Many kinds of form and size of goods F3 : Returnning or exchanging goods

: Students who bought

$O$ : Students who did't buy

: Women who bought

: Women who didn't buy

$* \mathrm{P}<0.05, * * \mathrm{P}<0.01$
換」の 3 因子が抽出された.

これらの 3 因子について, 因子得点を比較したと ころ, 通販利用者は非利用者よりもサイズと品数の 豊富さを重視し，返品・交換をする意識が低いこと がわかった。

そして, 試着・計測については, 社会人より大学 生の方が恥ずかしく感じていることがわかった。

\section{謝 辞}

本研究に当たり, 調查にご協力いただきました日 浦伸美さん，アンケートにご協力いただきました皆 様, そして，データ処理をご指導いただきました高 知大学情報処理センターに深謝します.

\section{引用文献}

1）被服心理学研究会分科会編；被服心理学, 日本緎維機械学 会, 大阪, (1988)

2）藤原康晴弓；蟣機誌，43，p421（1990）

3) 中川早苗; 蟣機誌, 34, p119 (1981)

4）田村和子ら；織機誌，45，p84（1992）

5）被服学体系化分科会編；社会心理学的方法，被服科学総論 (下巻)，日本紻維機械学会，大阪，114（1981） 